\title{
PORTFOLIO AND BENCHMARK RETURNS OF PRIVATE PENSION FUNDS: A COMPARATIVE ANALYSIS FOR TURKEY
}

\author{
Fatih KAYHAN 1 \\ Mehmet İSLAMOĞLU 2 \\ Mehmet APAN ${ }^{3}$
}

Received Date (Başvuru Tarihi):

$10 / 09 / 2020$

Accepted Date (Kabul Tarihi):

$3 / 11 / 2020$

Published Date (Yayın Tarihi):

$25 / 12 / 2020$

In the article, the first author is in the role of Corresponding Author.

\begin{abstract}
The purpose of this study is to ascertain whether pension fund returns are in line

Keywords:

Pension Funds,

Portfolio Returns,

Benchmark Returns

JEL Codes: with benchmark returns taking into account the regulatory structure in Turkey. The
methodology of the study is the cumulative portfolio returns. Data is retrieved from TEFAS Platform and official web site of Capital Market Board of Turkey. Portfolio and benchmark of pension funds are compared. Only standard pension funds are covered within the scope of voluntary pension funds of Turkey. Findings are as follows; Portfolio returns and benchmark returns are in line significantly. The results are partly attributable to the regulations about pension fund management and portfolio structure. The paper also shows that in the long term, the volatility of returns decreases and returns prove to conform with the primary purpose of the private pension system.
\end{abstract}

G15, G23, H55

\section{BİREYSEL EMEKLİLIK FONLARININ PORTFÖY VE KARŞILAŞTIRMA ÖLÇÜTÜ GETIRISII: TÜRKIYE İÇİN MUKAYESELİ ANALİZ}

$\ddot{O Z Z}$

\section{Anahtar Kelimeler: \\ Emeklilik Fonlarl, \\ Portföy Getirileri, \\ Benchmark Getirileri}

JEL Kodlarn:

G13, G23, H55
Çalışmanın amacı, Türkiye'de mevzuat altyapısını da dikkate alarak emeklilik fonları portföy getirilerinin karşılaştırma ölçütü getirileri ile benzer olup olmadığını tespit etmektir. Çalışmada, kümülatif portföy getirileri yöntemi kullanılmıştır. Veri kaynă̆ı TEFAS Platformu ve Sermaye Piyasası Kurulu'nun resmi web sitesidir. Emeklilik yatırm fonlarmın portföy ve karşılaştırma ('benchmark') ölçütü getirileri karşılaştırmalı olarak analiz edilmiştir. Yalnızca, Türkiye'de faal olan standart emeklilik yatırım fonları kapsama dahil edilmiştir. Çalışma bulguları göstermiştir ki, portföy ve karşılaştırma ölçütleri önemli ölçüde benzerlik arzetmektedir. Çalışma bulguları büyük ölçüde Türkiye'de mer'i olan emeklilik mevzuatı düzenlemeleri (portföy yönetimi ve portföy yapısı) neticesinde ortaya çıkmaktadır. Makale ayn zamanda göstermektedir ki, uzun vadede getiri volatilitesi azalmaktadır ve getiriler bireysel emeklilik sistemi kuruluş amaçlarıla uyumludur.

\footnotetext{
${ }^{1}$ Assistant Professor, Krrklareli University, fatih.kayhan@klu.edu.tr,

2 Associate Professor, Karabuk University, mehmetislamoglu@karabuk.edu.tr,

3 Assistant Professor, Karabuk University, mehmetapan@karabuk.edu.tr,
}

https://orcid.org/0000-0001-7844-8663 https://orcid.org/0000-0002-4416-0888 https://orcid.org/0000-0001-9471-4810

Business \& Management Studies: An International Journal Vol::8 Issue:5 Year:2020, 3891-3910

Bu makale, araştırma ve yayın etiğine uygun hazırlanmış ve itihenticate intihal taramasından geçirilmiştir. 


\section{INTRODUCTION}

The pension system is crucial for all economies concerning savings, retirement benefits, the burden of longevity on budget. In order to increase total savings, to increase the welfare of the people in the retirement age as well as to ease the burden of financing elderly, governments introduced private pension system in addition to the existing public pension system.

OECD Global Pension Statistics (OECD Pension Markets in Focus 2019) indicate that pension assets have been growing since 2010; globally, total assets reached USD 44.1 trillion at the end of 2018. This long-term trend is mainly due to positive real net returns over the long term. Additionally, there has been an increase in clientcontributions through recent mandatory or auto-enrolment programs.

Pension funds, critical instruments of private pension systems, increase total savings and investments, in turn, economic growth enhancement is ensured. This very fact has to do with the macroeconomic side of the private pension funds. Apart from that, the private pension system as a division of life-branch of total insurance industry enables the retired to sustain their relative purchasing power compared to their working life.

Why is the subject of this study important? Comparative analysis of portfolio \& benchmark returns of the private pension funds is of great significance. Funds have to follow benchmarks. Therefore, fund returns are to be in line with benchmark returns. The motivation of this paper is to find out whether fund returns and benchmark returns are in line or not (within the scope of Turkish Voluntary Private Pension funds,) in particular standard pension funds. Standard funds constitute the largest class of funds in Turkey by legal requirement (establishment criteria for the onset of pension business line). Contributors/clients of the private pension system expect the fund returns to conform with the benchmark (market indicator) returns. For instance, those who invest in stock funds expect that periodical fund returns are in line with stock market returns. 
Annual growth rate between end-2008 and end-2018 (or longest period available)

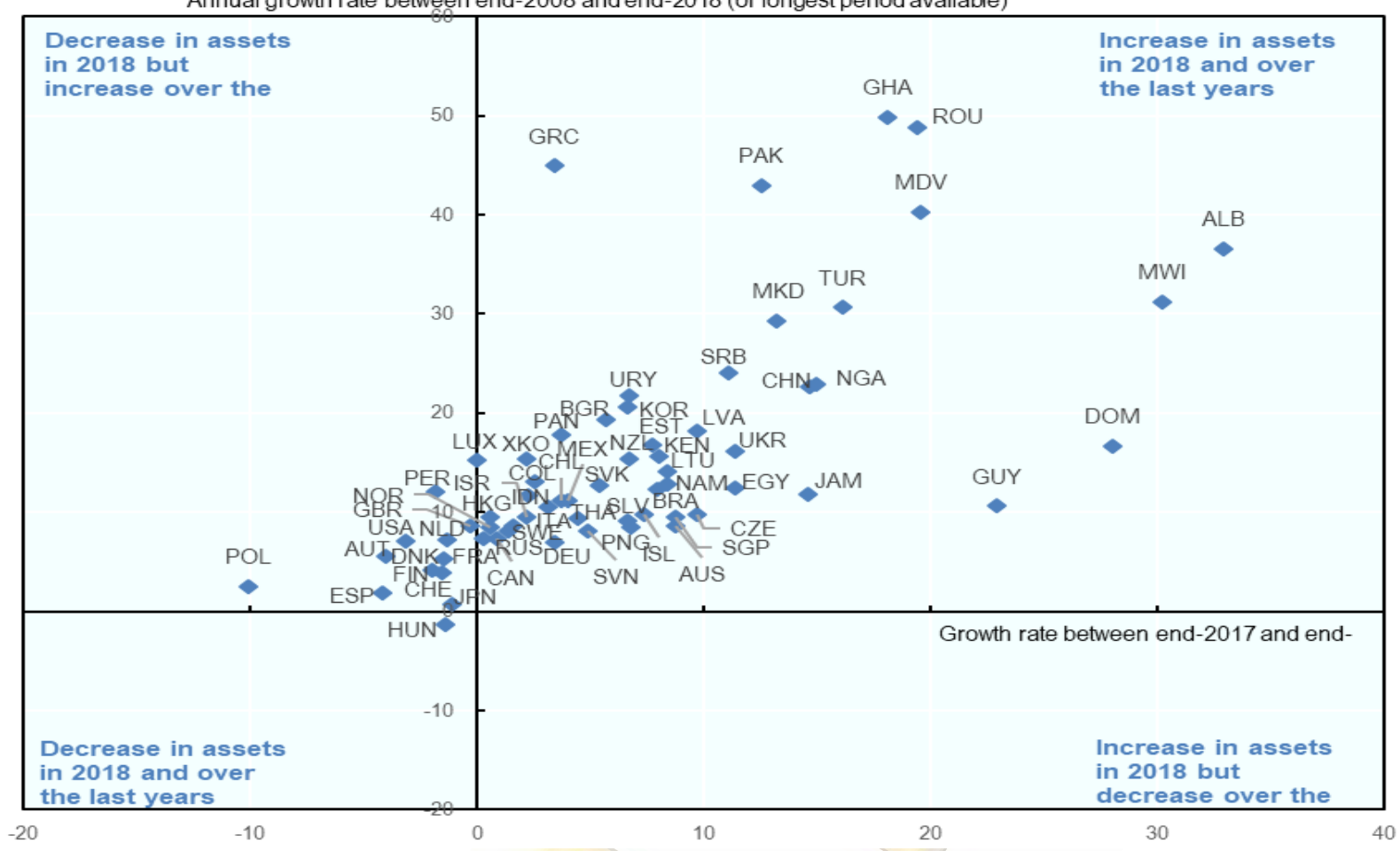

Figure 1. Annual Nominal Growth Rates of Assets in Pension Plans (\%)

Source: OECD Pension Markets in Focus 2019

Figure 1 is between end-2017 and end-2018 and between end-2008 and end-2018 (or most extended period available) in selected OECD and other jurisdictions. As can be seen from the above figure that is provided by OECD Global Pension Statistics, Turkey's (indicated as ISO code of 'TUR') annual nominal growth rate of assets (of pension plans) is considerable when compared to other OECD countries.

Private pension funds are crucial elements of the pension system. Portfolio management and portfolio returns are essential for the success of the system in that if portfolio returns (performance) are satisfactory for the participants, they will continue to stay in the system, they opt for increasing the contribution to the system/plan, then portfolios of the funds grow. In this way, specified goals (of private pension system) are achieved regarding the stable level of savings, sustained purchasing power of the retired as well as stable budget (less variance in the budget).

The study covers the private pension system, IPS ('BES') in Turkey with data mainly retrieved from the official webpage of The Capital Market Board and Pension Monitoring Authority. 1-Year (2017, 2018 and 2019) and 3 Year Returns are analysed 
via data retrieved from TEFAS, Turkey Electronic Fund Trading Platform. The methodology of cumulative benchmark returns is employed.

Upon the fact that Social security system in Turkey was considered to be unsustainable due to significant social security transfers from the state, a private pension system was needed. Another way of saying, Turkey was faced with expensive public pension system associated with unfunded liabilities. Ertuğrul, Gebeşoğlu, Atasoy (2018) argue that since domestic savings are not adequate in Turkey, the potential of sustainable growth is constrained in the long term; also, inadequate domestic savings cause the economy to be more dependent on foreign capital flows.

Therefore, voluntary private pension system, IPS ('BES') was introduced in 2001 and became effective in 2003. This new voluntary private pension system is considered to be the third pillar based on defined contribution. The first pillar is the public pension system (social security system). Auto-Enrolment System ('AES') introduced in 2007 (effective in 2008) is named as the second pillar (together with old second pillar applied by some firms providing a private pension for their employees, occupational savings schemes ('munzam sandık'). Antolin (2008) reviews pension fund performance by providing an analysis of aggregate investment performance by country on a riskadjusted basis, indicates that occupational pension plans in OECD countries are mainly defined benefit plans ('DB'). However, defined contribution plans ('DC') are replacing them in many countries.

Contrary to popular belief, pension companies do not sell pension funds directly, they sell only pension plans to their clients (participants) and pension plans are composed of private pension funds. In turn, private pension funds are made up of fund portfolios plus other items (liquid assets, other receivables and payables, which are minor when compared to fund portfolios). Fund portfolios are composed of different asset classes/investment tools (stocks, bond/Sukuk, deposits/profit share accounts, mutual fund, gold, foreign exchange) depending on the nature of the fund, which is specified in the regulation.

As far as regulatory bodies of the private pension funds (and the system as a whole) are concerned, Capital Markets Board of Turkey ('CMB' /'SPK'), which was 
established in 1982, regulates the establishment, operations of pension companies and also regulates the structure of fund portfolio. Besides, The Ministry of Treasury and Finance (issues legislation concerning state contribution) and Pension Monitoring Authority are the leading regulatory \& supervisory bodies.

As for the legislation, the main primary legal document is the Private Pension Savings and Investment System Law No. 4632 ('law') (Acceptance Date 28 March 2001). There exist several secondary-law documents, but the leading ones are considered to be the Regulation no. 28586 on pension funds ('SPK EYF Yönetmelik') issued by Capital Market Board on 13 March 2013 and Pension Fund Guide ('EYF Rehber') by Capital Markets Board Resolution, 2016/7). Regulations (secondary-law items) issued by the Ministry of Treasury and Finance related to state contribution are also significant legal documents governing the system. In addition to these, within the framework of this study, another important legal document is the communique (VII128-5) issued by the Capital Market Board on fund performances dated 17 December 2013.

The private pension system is run by 16 retirement companies (life and pension companies) in Turkey as of 1 November 2020. Not all life insurance companies provide pension products. Private pension plans made of pension funds are insurance products.

The difference between IPS (BES) and AES is explained in the official web site of Turkish Pension Monitoring Authority (https://egm.org.tr/auto-enrollmentsystem-aes/aes--ips-comparison/): IPS is an entirely voluntary pension system. In this system, members are entitled to the full amount of pension benefits when they reach the age of 56 (participants have to stay in this system for a minimum of ten years). As opposed to the third pillar (IPS), AES is mandatory for employers, and the contribution rate for the employees starts at 3 per cent of the salary. That is, all employees (public personnel plus private personnel) younger than the age of 45 are automatically enrolled in this system and are assigned to a pension plan. In AES, employees contribute 3 per cent of their taxable earnings. However, when they wish to quit in writing, they are permitted to quit the system after a 2-month enrolment period. 
For BES and AES, pension companies establish the funds, operate them, but only portfolio companies have the exclusive authority to manage the funds because the system is based on the idea of professional management of the funds.

Pension companies have the option to outsource basic operations of the funds, but pension companies have the ultimate liabilities to the regulatory authorities.

According to recent figures in the official website of Pension Monitoring Authority of Turkey as of 23 October 2020 (https://egm.org.tr/), the asset size of IPS (BES) funds (Assets Under Management) is TL 152.8 million (excluding the AES participants). Regarding AES, the total number of participants is about 5.6 million, with total AuM TL 11 billion.

Contribution of this study to the literature is made through providing the updated (and comprehensive) operational and regulatory structure of Turkish Pension Fund Industry. Furthermore, this study furnishes a comparison of benchmark and fund returns through yearly and cumulative returns of 3-year.

The research question of this paper is that: Does pension fund returns significantly miss benchmark returns within the scope of Turkish voluntary pension system? Are returns of a voluntary private pension fund (portfolio) in line with their benchmark returns significantly?

As benchmarks, we take into account leading market indicators (stock market, bond market as well as alternative/conventional investment tools like gold, foreign exchange, deposit/profit share account) and analyse the relation between market returns (benchmark) and fund returns.

This paper's objective is to find an answer to this question by comparing standard pension fund returns and corresponding benchmark returns (related 'government bond index').

The paper proceeds as follows: Section I is the introduction part where general information about Turkish pension systems, performance structure of private pension funds is provided. In Section II, literature is reviewed. In Section III, methodology and 
data are provided. Section IV provides the findings of the study. Section V concludes and provides discussions.

\section{LITERATURE REVIEW}

The necessity of a benchmark is underlined in studies, Brinson et al. (1986) argue that focusing of investment attention on the asset structure of the total portfolio is needed in order to ensure successful management of a pension plan portfolio. Good management of pension portfolio is available with the help of a composite benchmark portfolio called multiple market index.

Blake et al. (1999) use a data set on UK pension funds' asset holdings and examine the relationship between asset allocation dynamics and pension fund performance. They argue that strategic asset allocation accounts for most of the timeseries variation in portfolio returns. Apart from this finding, they also allege that market timing and asset selection are less significant for fund performances.

We look at previous studies about fund performance, their asset allocation decisions and the riskiness of investments. For example, Alestalo and Puttonen (2006) contend that there is a connection between liability structure and asset allocation. Assets of the pension funds that younger clients predominantly prefer are structured upon stocks (shares prevail in the fund portfolio). On the other hand, portfolios of assets of (comparatively more) mature funds are mostly made up of fixed income instruments (like bonds, deposits).

Albrecht and Hingorani (2006) examine the impacts of governance practices and investment strategies on state and local government pension fund financial performance and argue that these have an indirect impact on the fund performance, however direct impacts are more influential than direct impacts.

Regarding the relation between pension fund management industry and individual and occupational private pension funds, Tonks (2006) argues that the value of a pension fund goes up with contributions and investment returns on the fund. Additionally, it is argued in this study that these investment returns are dependent on fund managers' decisions on asset allocation and portfolio. 
Reviewing determinants of performance of pension funds to provide retirement income to the clients (contributors of the system) Hinz et al. (2010) argue that when short-term nominal returns on investments become the only focus of attention, the following fact is ignored that returns are solely one of the factors determining the performance. Other elements that affect the overall performance include administrative costs and management costs, the density of contributions as well as the behaviour of participants in choosing a retirement age.

While reviewing the returns of pension funds and comparing them with corresponding benchmarks, real returns rather than nominal returns should be taken into account. Berthon et al. (2013) refer to OECD figures by providing real returns for several countries and show that real returns of pension funds (returns after inflation) were negative between 2007-2011 for many EU member countries. This very fact indicates that whether pensioners' purchasing power is held against inflation is of great significance.

A study by Gökçen and Yalçın (2015) indicate that active investing (a significant amount of trade in a fund portfolio rather than simply following up a specified benchmark) did not perform better than the passively invested pension funds using data on private Turkish pension industry.

Regarding governance and fund performance, Ammann et al. (2017) study the relation between the concept of governance, investment performance and pension funds' asset allocation in Switzerland and find that there is a positive relationship between pension fund performance and excess returns, benchmark out-performance and Sharpe ratios.

Focusing on benchmark selection and performance, Broeders and Haan (2018) review 455 Dutch Pension Funds for the years 2017-2016 and search for the impact of benchmark selection on the variation of pension fund returns. By way of crosssectional analysis, they found that -over time and across pension funds- benchmark selection is more important than security selection and market timing concerning fund returns. 
Kuzubaş et al. (2019) study performance evaluation of the Turkish Pension Fund System with an in-depth analysis of the private pension funds and argue that majority of the pension funds cannot provide an excess return, a positive Alfa cannot be generated when the majority of the funds' returns are examined.

The literature on pension funds is primarily based on capital market development and the pension system. Most of the literature confirms that private pension funds support capital markets, which is applicable also for Turkey (Bayar 2017).

Şahin et al. (2018) study the effects of individual pension funds on capital market development in Turkey, using monthly data for the period 2006-2017; and they suggest that individual pension funds support stock market development in the long term.

Toğan-Eğrican and Kayhan (2020) find similar evidence when they use Turkey stock market and bond market data and maintain that voluntary pension funds are associated positively with various capital market indicators.

\section{DATA AND METHODOLOGY}

Data for rate of returns for funds are retrieved from the official webpage of Turkish Capital Markets authority ('SPK') and 'TEFAS' platform (run by TAKASBANK- Istanbul Clearing, Settlement and Custody Bank) for the last five years. For computing rate of returns of benchmark investment tools, data from 'BISTConnect Platform' (run by 'Borsa-Istanbul'), Turkish Statistical Institute-TUIK and Central Bank of Turkey is also used in this study. General information about the private pension system is received from EGM ('Emeklilik Gozetim Merkezi'), the pension monitoring authority in the system.

The methodology used in this study is cumulative-portfolio-returns. Rate of returns of Turkish pension funds and their respective benchmarks are computed by employing the method of cumulative portfolio returns for 3-year (together with yearly returns for 2019-2018-2017 in order to comprehend, review and compare the yearly rate of returns). 
Periodical rate of return (for both fund portfolio and related benchmark) is calculated simply by taking the difference of last and first price (for any period) and dividing the computed difference by the first price. Subtracting the daily price/value of the first date from that of the last date (for the selected period) and dividing this value by the daily price/value of the first date gives the rate of return of the fund (portfolio) or the benchmark. For every single fund that pension fund companies set up and operate, they are to release the daily fund price. Ensuring reconciliation of this price is a must (Reconciliation is ensured by pension company and Takasbank mutually).

The term 'fund' and 'fund portfolio' are different terms in that fund refers to 'sum of portfolio assets plus other receivables minus payables', while 'portfolio' accounts for only 'sum of assets' held in the fund excluding other receivables and payables. The portfolio of a fund composes significant part of a fund (that is, portfolio constitutes the most of the fund). For this study, this difference is intentionally ignored; fund and fund portfolio are used synonymously.

'Pension Fund Report-2020, Special Issue of Forbes Turkey' argues that in 2019 interest rate cuts by FED, decreasing policy interest rates by Central Bank of Turkey after the second half of the year brought about a good atmosphere for financial markets. Then, relatively stable foreign currency rates against domestic currency together with decreasing inflation and decline in cost of borrowing caused domestic stock market index (BIST-100) to go up remarkably.

This favourable atmosphere had positive repercussions on performance yields of the pension funds. Almost all investors/participants of the private pension system had the opportunity to get a high rate of return in the face of the rate of inflation (Consumer Price Index (CPI) $2019=11.84 \%$ ).

Capital Market Board determines the general framework of asset classes of the funds and types of funds: Stock funds, borrowing instrument (fixed-income) funds, participation funds (non-interest funds), mixed funds, money market funds ('liquid funds'), precious metal funds, index funds, fund basket funds, state contribution funds, variable funds, standard funds and life-cycle-funds. Portfolio of a pension fund 
is composed of different asset classes (stocks, bonds, deposits and money market instruments).

In the case of Turkey, the portfolio of each fund type is highly regulated, fund limitations are determined and closely monitored by the Capital Market Board. The funds (except for variable/flexible ones) are to follow the benchmark closely by the related regulations. For example, for a fund to be named as a 'stock fund', its fund portfolio must include stocks with a minimum ratio of $80 \%$ of the total portfolio. On average, pension funds' objective is to meet or exceed the rate of return of policy benchmark. Table 1 indicates returns of the leading (financial) investment tools as indicated by Index provided daily by BIST-Connect, which is a financial product run by Borsa-Istanbul (Istanbul Stock Exchange). For the performance returns, 2019 turned out to be a good year for most of the financial investment tools, stocks, bonds, deposits thanks to favourable domestic and foreign financial conditions in the markets.

Table 1. Yearly Average Returns of Financial Instruments (Index)

\begin{tabular}{|c|c|c|c|c|c|c|}
\hline INDEX CODE & 1Y- 2019 & 1Y- 2018 & 1Y- 2017 & $\begin{array}{c}3 Y \\
(2017-2019)\end{array}$ & $\begin{array}{c}5 Y \\
(2015-2019)\end{array}$ & $\begin{array}{c}10 Y \\
(2010-2019)\end{array}$ \\
\hline Participation-30 & $49.8 \%$ & $-19.8 \%$ & $36.7 \%$ & $21.5 \%$ & $12.9 \%$ & - \\
\hline Gold Index (IAB TL/ Kg.) & $33.3 \%$ & $39.0 \%$ & $18.8 \%$ & $40.1 \%$ & $44.9 \%$ & $42.3 \%$ \\
\hline BIST-KYD- GDS ALL & $31.4 \%$ & $2.2 \%$ & $7.8 \%$ & $15.0 \%$ & $12.0 \%$ & $15.1 \%$ \\
\hline BIST-KYD Govt Lease Certificate & $28.8 \%$ & $10.5 \%$ & $7.9 \%$ & $17.9 \%$ & $16.2 \%$ & - \\
\hline BIST-KYD Corp. Bond Floating Rate & $26.8 \%$ & $19.9 \%$ & $15.6 \%$ & $25.3 \%$ & $23.3 \%$ & - \\
\hline BIST-100 & $24.6 \%$ & $-20.4 \%$ & $47.6 \%$ & $15.5 \%$ & $6.7 \%$ & $11.7 \%$ \\
\hline BIST-KYD Corporate Bond Fixed Rate & $22.0 \%$ & $18.3 \%$ & $12.5 \%$ & $20.8 \%$ & $19.4 \%$ & - \\
\hline BIST-KYD Private Lease Certificates & $21.2 \%$ & $17.0 \%$ & $11.8 \%$ & $19.6 \%$ & $18.9 \%$ & - \\
\hline BIST-KYD O/N (Net) & $19.0 \%$ & $15.5 \%$ & $10.1 \%$ & $17.1 \%$ & $15.5 \%$ & $14.1 \%$ \\
\hline Deposit Monthly (Net) & $16.3 \%$ & $14.7 \%$ & $9.0 \%$ & $15.1 \%$ & $14.0 \%$ & $13.7 \%$ \\
\hline BIST-KYD Profit Share (TL) & $15.8 \%$ & $11.4 \%$ & $8.4 \%$ & $13.3 \%$ & $12.3 \%$ & - \\
\hline USD & $12.9 \%$ & $39.5 \%$ & $7.2 \%$ & $23.0 \%$ & $31.1 \%$ & $29.8 \%$ \\
\hline Inflation (CPI) & $11.8 \%$ & $20.3 \%$ & $11.8 \%$ & $16.8 \%$ & $15.6 \%$ & $15.8 \%$ \\
\hline EUR & $10.7 \%$ & $33.3 \%$ & $21.7 \%$ & $26.5 \%$ & $27.1 \%$ & $21.0 \%$ \\
\hline Average & $24.0 \%$ & $13.9 \%$ & $16.5 \%$ & $20.8 \%$ & $19.6 \%$ & $21.1 \%$ \\
\hline Standard Deviation & $10.4 \%$ & $18.7 \%$ & $12.4 \%$ & $7.1 \%$ & $10.1 \%$ & $11.2 \%$ \\
\hline
\end{tabular}

Note: 'YD refers to Institutional Investors' Association, 'GDS refers to Government Debt Security.

Source: Created by Author by (via data from BIST-Connect) 
Table 1 clearly shows that financial instruments that are the base products upon which the pension funds' portfolios are formed prove to be more yielding (profitable) on average when they are held for long term (3-year, 5-year) rather than yearly periods. Although the year 2019 performances are very high on average, it is a wellknown fact that average returns are not $24 \%$ for the previous years every year.

Additionally, long term period (average return) variance is relatively low when compared to yearly return variances. These results affect fund performances. We expect similar results in the fund returns because funds follow benchmarks.

In Turkey, Pension funds' average return turned out to be $25 \%$ in 2019 . Performance (returns/yields) of the funds are determined mainly by the following variables; market returns (stock market, bond market), performance of fund portfolio manager (asset allocation, asset selection by portfolio manager), fees/commissions charged.

Except for state contribution funds, pension companies are free to determine the fund management fee, which constitutes the most significant part of the total fee charged. The average management fee for all the funds is around 2 per cent calculated out of fund total portfolio. The calculated management fee is the income for pension companies for pension business. The management fee is shared by pension company and portfolio company managing the fund, in practice, most of this fee is received by the pension company (as income). The pension company and portfolio freely decide management fee sharing (rates) with a portfolio management agreement. Apart from these, regulations play a significant role in the performance of the fund. For example, if the state contribution fund portfolio is made to be composed of long-term bonds compulsorily by regulation, the increase in interest rates may cause the returns to remain low.

From another point of view, it can be safely asserted that an increase in AuM of every single private pension funds stems either by contributions made by clients (participants) or market returns. Another way of saying, contributions/exits from a fund or related market yields that affect the fund portfolio determine the incline or decline in AuM of the funds. In this study, among all funds, standard funds are elected 
for the analysis because these funds are compulsory funds to be established by the pension companies by regulations; and these funds are most-offered-funds for clients (participants), and in turn, these are the funds with the biggest AuM among all fund groups. It is very reasonable to take this fund group as a leading benchmark for all fund groups within the scope of this study. Standard funds hold government debt securities (bonds) heavily in the fund portfolio (60\% of the fund portfolio is to be invested in government debt instruments) by regulation.

Table 2. Returns of Standard Pension Funds in 2019 (Turkey)

\begin{tabular}{|l|l|c|}
\hline \multicolumn{1}{|c|}{ Fund Code } & \multicolumn{1}{|c|}{ Fund Name } & Return \% \\
\hline ANG & AEGON EMEKLILIK VE HAYAT A.Ş. STANDARD PENSION MUTUAL FUND & 28.8 \\
\hline AMS & ALLIANZ YAŞAM VE EMEKLILIK A.Ş. STANDARD PENSION MUTUAL FUND & 28.6 \\
\hline AZS & ALLİANZ HAYAT VE EMEKLILIK A.Ş. STANDARD PENSION MUTUAL FUND & 28.4 \\
\hline ATK & ANADOLU HAYAT EMEKLILIK A.Ş. STANDARD PENSION MUTUAL FUND & 28.3 \\
\hline AVN & AVIVASA EMEKLİLIK VE HAYAT A.Ş. STANDARD PENSION MUTUAL Fund & 27.5 \\
\hline HEK & AXA HAYAT VE EMEKLILIK A.Ş. STANDARD PENSION MUTUAL FUND & 27.2 \\
\hline BNS & BNP PARIBAS CARDİ EMEKLILIK A.Ş. STANDARD PENSION MUTUAL Fund & 28.3 \\
\hline CHS & CIGNA FINANS EMEKLILIK VE HAYAT A.Ş. STANDARD P.M.F & 26.5 \\
\hline EST & FiBA EMEKLILIK VE HAYAT A.Ş. - OYAK ASSET MAN. STD PENSION MUTUAL Fund & 29.1 \\
\hline FEN & FiBA EMEKLILIK VE HAYAT A.Ş. STANDARD PENSION MUTUAL Fund & 23.7 \\
\hline GHD & GARANTI EMEKLILIK VE HAYAT A.Ş. STANDARD PENSION MUTUAL Fund & 27.8 \\
\hline MHK & METLIFE GOVT BONDS AND BILLS STANDARD PENSION MUTUAL Fund & 28.2 \\
\hline IEB & NN HAYAT VE EMEKLILIKK GOVT BONDS AND BILLS STD. PENSION MUT. FUND & 27.1 \\
\hline HHK & HEM GOVT BONDS AND BILLS STANDARD PENSION MUTUAL FUND & 25.1 \\
\hline VEK & VEM STANDARD PENSION MUTUAL FUND & 27.7 \\
\hline ZHS & ZEM STANDARD PENSION MUTUAL FUND & 24.9 \\
\hline & & $\mathbf{2 7 . 3}$ \\
\hline
\end{tabular}

\section{Source: TEFAS}

Table 2 indicates that average return of $27.3 \%$ for standard funds (the funds with greatest AuM among all fund types) in 2019 conforms with that of BIST-KYDGDS-ALL (31.4\%), which is the indices (in a way 'a benchmark') related to all government debt instruments. The difference can be explained by the relatively low average returns of other portfolio items like time-deposits, $\mathrm{O} / \mathrm{N}$ that constitute the whole fund portfolio. 
Table 3. Returns of Standard Pension Funds in 2018 (Turkey)

\begin{tabular}{|c|c|c|}
\hline Fund Code & Fund Name & Return \% \\
\hline ANG & AEGON EMEKLİLIK VE HAYAT A.Ş. STANDARD PENSION MUTUAL FUND & 6.0 \\
\hline AMS & ALLIANZ YAŞAM VE EMEKLİLIK A.Ş. STANDARD PENSION MUTUAL FUND & 4.7 \\
\hline AZS & ALLİANZ HAYAT VE EMEKLİLIKK A.Ş. STANDARD PENSION MUTUAL FUND & 2.3 \\
\hline ATK & ANADOLU HAYAT EMEKLİLIK A.Ş. STANDARD PENSION MUTUAL FUND & 4.3 \\
\hline$\overline{\mathrm{AVN}}$ & AVİVASA EMEKLİLIKK VE HAYAT A.Ş. STANDARD PENSION MUTUAL Fund & 3.1 \\
\hline HEK & AXA HAYAT VE EMEKLİLIK A.Ş. STANDARD PENSION MUTUAL FUND & 3.9 \\
\hline BNS & BNP PARİBAS CARDİF EMEKLİLIK A.Ş. STANDARD PENSION MUTUAL Fund & 5.4 \\
\hline CHS & CİGNA FINANS EMEKLILİK VE HAYAT A.Ş. STANDARD P.M.F & 7.7 \\
\hline EST & FİBA EMEKLILIK VE HAYAT - OYAK ASSET MAN. STD PENSION MUTUAL Fund & 8.8 \\
\hline FEN & FIBA EMEKLİLIK VE HAYAT A.Ş. STANDARD PENSION MUTUAL Fund & 4.0 \\
\hline GHD & GARANTİ EMEKLİLIK VE HAYAT A.Ş. STANDARD PENSION MUTUAL Fund & 3.1 \\
\hline MHK & METLIFE GOVT BONDS AND BILLS STANDARD PENSION MUTUAL Fund & 4.8 \\
\hline IEB & NN HAYAT VE EMEKLİLİK GOVT BONDS AND BILLS STD. PENSION MUT. FUND & 3.9 \\
\hline HHK & HEM GOVT BONDS AND BILLS STANDARD PENSION MUTUAL FUND & 4.4 \\
\hline VEK & VEM STANDARD PENSION MUTUAL FUND & 15.3 \\
\hline ZHS & ZEM STANDARD PENSION MUTUAL FUND & 10.4 \\
\hline & Average & 5.8 \\
\hline
\end{tabular}

Table 4. Returns of Standard Pension Funds in 2017 (Turkey)

\begin{tabular}{|l|l|c|}
\hline Fund Code & \multicolumn{1}{|c|}{ Fund Name } & Return \% \\
\hline ANG & AEGON EMEKLILIK VE HAYAT A.Ş. STANDARD PENSION MUTUAL FUND & 6.4 \\
\hline AMS & ALLIANZ YAŞAM VE EMEKLILIK A.Ş. STANDARD PENSION MUTUAL FUND & 10.5 \\
\hline AZS & ALLİANZ HAYAT VE EMEKLİLIK A.Ş. STANDARD PENSION MUTUAL FUND & 10.8 \\
\hline ATK & ANADOLU HAYAT EMEKLİLIK A.Ş. STANDARD PENSION MUTUAL FUND & 8.0 \\
\hline AVN & AVIVASA EMEKLILIK VE HAYAT A.Ş. STANDARD PENSION MUTUAL Fund & 7.1 \\
\hline HEK & AXA HAYAT VE EMEKLILIKK A.Ş. STANDARD PENSION MUTUAL FUND & 6.8 \\
\hline BNS & BNP PARİBAS CARDİF EMEKLILIK A.Ş. STANDARD PENSION MUTUAL Fund & 9.0 \\
\hline CHS & CIGNA FINANS EMEKLILIK VE HAYAT A.Ş. STANDARD P.M.F & 10.8 \\
\hline EST & FIBA EMEKLILIK VE HAYAT -OYAK ASSET MAN. STD PENSION MUTUAL Fund & 6.9 \\
\hline FEN & FİBA EMEKLİLIK VE HAYAT A.Ş. STANDARD PENSION MUTUAL Fund & 8.7 \\
\hline GHD & GARANTI EMEKLILIK VE HAYAT A.Ş. STANDARD PENSION MUTUAL Fund & 8.1 \\
\hline MHK & METLIFE GOVT BONDS AND BILLS STANDARD PENSION MUTUAL Fund & 6.8 \\
\hline IEB & NN HAYAT VE EMEKLILIKK GOVT BONDS AND BILLS STD. PENSION MUT. FUND & 7.4 \\
\hline HHK & HEM GOVT BONDS AND BILLS STANDARD PENSION MUTUAL FUND & 6.3 \\
\hline VEK & VEM STANDARD PENSION MUTUAL FUND & 8.9 \\
\hline ZHS & ZEM STANDARD PENSION MUTUAL FUND & 8.6 \\
\hline & & 8.2 \\
\hline
\end{tabular}


For 2018 and 2017, as indicated in Table 3 and 4, average returns for the very same fund group are meagre $(5.8 \%$ and $8.2 \%)$ in comparison to 2019 average returns (due to bond market returns).

Table 5. Returns of Standard Pension Funds for 3 Years (2017-2019)

\begin{tabular}{|l|l|c|c|}
\hline \multicolumn{1}{|c|}{$\begin{array}{c}\text { Fund } \\
\text { Code }\end{array}$} & \multicolumn{1}{|c|}{ Fund Name } & $\begin{array}{c}\text { Return } \% \\
\text { Yearly Return } \\
\text { Equivalent } \% \\
\text { for } \mathbf{3} \text { Years }\end{array}$ \\
\hline ANG & AEGON EMEKLILIK VE HAYAT A.Ş. STANDARD PENSION MUTUAL FUND & 46.9 & 15.6 \\
\hline AMS & ALLIANZ YAŞAM VE EMEKLILIK A.Ş. STANDARD PENSION MUTUAL FUND & 50.6 & 16.9 \\
\hline AZS & ALLİANZ HAYAT VE EMEKLILIKK A.Ş. STANDARD PENSION MUTUAL FUND & 47.5 & 15.8 \\
\hline ATK & ANADOLU HAYAT EMEKLİİK A.Ş. STANDARD PENSION MUTUAL FUND & 46.5 & 15.5 \\
\hline AVN & AVIVASA EMEKLILIK VE HAYAT A.Ş. STANDARD PENSION MUTUAL Fund & 42.2 & 14.1 \\
\hline HEK & AXA HAYAT VE EMEKLILIKK A.Ş. STANDARD PENSION MUTUAL FUND & 42.8 & 14.3 \\
\hline BNS & BNP PARIBBAS CARDİF EMEKLILIK A.Ş. STANDARD PENSION MUTUAL Fund & 48.8 & 16.3 \\
\hline CHS & CIGNA FINANS EMEKLILIK VE HAYAT A.Ş. STANDARD P.M.F & 52.2 & 17.4 \\
\hline EST & FİBA EMEKLILIK VE HAYAT A.Ş. OYAK ASSET MAN. STD PENSION MUT. Fund & 51.2 & 17.1 \\
\hline FEN & FİBA EMEKLİİK VE HAYAT A.Ş. STANDARD PENSION MUTUAL Fund & 41.2 & 13.7 \\
\hline GHD & GARANTI EMEKLILIK VE HAYAT A.Ş. STANDARD PENSION MUTUAL Fund & 43.7 & 14.6 \\
\hline MHK & METLIFE GOVT BONDS AND BILLS STANDARD PENSION MUTUAL Fund & 45.0 & 15.0 \\
\hline IEB & NN HAYAT VE EMEKLILIK GOVT BONDS AND BILLS STD. PENSION M. FUND & 42.8 & 14.3 \\
\hline HHK & HEM GOVT BONDS AND BILLSSTANDARD PENSION MUTUAL FUND & 39.8 & 13.3 \\
\hline VEK & VEM STANDARD PENSION MUTUAL FUND & 61.1 & 20.4 \\
\hline ZHS & ZEM STANDARD PENSION MUTUAL FUND & 50.4 & 16.8 \\
\hline & & $\mathbf{4 7 . 1}$ & $\mathbf{1 5 . 7}$ \\
\hline
\end{tabular}

Note: Yearly returns are computed by dividing cumulative ones into 3 .

Source: TEFAS

Table 5 provides $3 y$ returns of standard pension funds. Average yearly return of these funds is $15.7 \%$. The corresponding benchmark of these funds is BIST-KYDGDS ALL which is indie for Government Debt Instruments, the yearly average return of this benchmark is $15 \%$. Average fund returns and benchmark return are similar.

\section{FINDINGS}

Considering all these, main findings of these analyses are summarised as follows: When Table 5 (3Y standard fund returns) are compared to Table 1-Benchmark Returns it is seen that fund returns and benchmark returns are in line significantly. For $3 Y(2017-2019)$ average return of standard pension funds, $15.7 \%$, is very close to that 
of the benchmark (BIST-KYD-GDS ALL, an index for Government Debt Instruments) when yearly return equivalent is taken into account.

Another finding is that as can be seen from Table 5, the yearly equivalent of 3year cumulative returns is sustainable returns when compared to yearly returns that vary considerably from 2017 to 2019. Yearly returns are computed by dividing cumulative ones into 3.

Holding the funds for longer-term (3-year and longer) ensures sustainable returns with relatively low variance in returns in comparison to yearly returns, which is the reflection of the benchmark (leading investment tools) returns that are the base upon which the fund portfolios are generated.

Directing participants to hold the funds for longer terms rather than short terms (staying in the pension system for longer terms) is more profitable for participants of the private pension system. On the other hand, (on average) making frequent changes in fund baskets in a pension plan to make use of market advantages is not profitable for the participants of the pension system.

\section{CONCLUSION}

Turkey implemented a voluntary private pension system going into effect in 2003. We study the introduction of voluntary private pension funds in Turkey and comparative portfolio returns of funds versus benchmark returns.

This study aims to find out whether voluntary pension fund returns are in line with benchmark returns, given the regulations that specify strictly the framework of pension fund portfolio structures as well as benchmarks. The scope of the research is limited to Standard Pension Funds which are a significant part of the existing voluntary private pension system in Turkey.

Performance of voluntary pension funds is an important issue given the fact that sustainable pension system affecting savings, sustainable life standards of pensioners as well as stable budget is based on successful fund returns that are the key motivation for the investors (participants) of the system. 
Using data from TEFAS and Capital Market Board of Turkey, comparative returns of Turkish pension fund portfolios and their corresponding benchmarks are calculated; the method of cumulative portfolio returns is used for 3-year together with yearly returns for 2019-2018-2017. Periodical rate of return -for both fund portfolio and related benchmark- is calculated by taking the difference of last and first price (for any period) and dividing the computed difference by the first price.

In the study, findings that arise out of the comparison of cumulative returns of (standard) fund returns and respective benchmark returns provide an answer to the research question. In Turkey, voluntary private pension fund returns are found to be in line with returns of benchmark, which is an expected result considering the regulations. Regulations are designed in such a way that cause portfolios of the funds to have similar structures. The funds (excluding flexible ones) are to follow a specified benchmark. Therefore, the fund returns conform with those of benchmark that is specified in general as BIST-100, (TL/FX) bond or Sukuk, reverse-repo, deposit/profit share account, gold, foreign exchange. Therefore, it can be inferred that findings turn out to be close to expectations.

This paper discusses that those participants who invest in standard pension funds (mostly based on government bond) can make sure that fund returns are significantly in line with benchmark returns.

Policy recommendations of this paper are as follows:

- In order to make the most of private pension system (BES and AES) firstly, primary and secondary legislation should be designed in such a way that participants/investors of this system should be directed to long-term-stay in the system.

- Returns less than 3-the year in the official \& non-official reporting should be discouraged. Relatively long-term returns should take place in all reporting to divert participants' short-term perception / notion of a return to long-term. In this way, portfolio managers can be allowed to take a position with long-term vision.

- Long-term government debt instruments (bonds) should be issued, and 
these issues should be carried out frequently in order to increase the manoeuvrability of portfolio managers while managing pension fund portfolios given the fact that due to an insufficient number of long-term bonds, portfolio managers' ability to increase yields of funds is limited. Taking into account the minimum and maximum boundaries about portfolio limits, which are specified by Capital Market Board, this can be seen an effective way to increase the yields.

- The opportunity for the fund managers that are more successful in fund management to receive additional (fund management) income apart from the regular income they receive from the fund management fee, which is only in practice in AES, should also be in the IPS-Voluntary Private Pension System.

- There should be legal arrangements in terms of establishing new pension funds which are based only on 'venture capital fund' (GSYF) and 'real estate investment fund' (GYF). Moreover, deterrence should be provided for 2-3 years for outflows from these funds for the development of these funds.

- Flexibility should be achieved in the rules introduced for the selection of stocks that can be added to the fund portfolios within the scope of interest-free pension mutual funds. In this way, different stocks can be included in the portfolios of these funds and fund returns can be increased more.

Further research may be to review specifically other fund groups like stock funds, golden funds, money market funds for both conventional pension fund management and non-interest pension system. 


\section{REFERENCES}

Albrecht, W. G., \& Hingorani, V. L. (2004). Effects of Governance Practices and Investment Strategies on State and Local Government Pension Fund Financial Performance. International Journal of Public Administration, 27(8-9), 673-700.

Alestalo, N., \& Puttonen, V. (2006). Asset Allocation in Finnish Pension Funds. Journal of Pension Economics and Finance, 5(1), 27-44.

Ammann, M., \& Ehmann, C. (2017). Is Governance Related to Investment Performance and Asset Allocation? Empirical Evidence from Swiss Pension Funds. Swiss Journal of Economics and Statistics(153), 293-339.

Antolin, P. (2008). Pension Fund Performance. OECD Working Papers on Insurance and Private Pensions. Paris-France: OECD publishing.

Bayar, Y. (2017). Individual Pension Funds and Capital Market Development in Turkey. Review of Economic and Business Studies, 9(2), 95-109.

Berthon, J., Cronin, C., Prache, G., Struwe, K., \& Viver, J. M. (2013). Private Pensions: The Real Return. A Research Report by EuroFinUse The European Federation of Financial Services Users. BrusselsBelgium: $\quad$ EuroFinUse. https:// betterfinance.eu/wpcontent/uploads/publications/Pension_Study_EN_website.pdf

Blake, D., Lehmann, B. N., \& Timmermann, A. (1999). Asset Allocation Dynamics and Pension Fund Performance. The Journal of Business, 72(4), 429-461.

Brinson, G. P., Diermeier, J. J., \& Schlarbaum, G. G. (1986). A Composite Portfolio Benchmark for Pension Plans. Financial Analysts Journal, 42(2), 15-24.

Broeders, D., \& Haan, L. d. (2018). Benchmark Selection and Performance. Working Paper No. 603. Amsterdam-The Netherlands: De Nederlandsche Bank NV.

CMB. (2020). Capital Markets Board of Turkey. www.cmb.gov.tr

EGM. (2020). Pension Monitoring Authority of Turkey (Emeklilik Gözetim Merkezi). www.egm.org.tr Ertuğrul, H. M., Gebeşoğlu, P. F., \& Atasoy, B. S. (2018). Mind the Gap: Turkish Case Study of Policy Change in Private Pension Schemes. Borsa Istanbul Review, 18(2), 140-149.

Forbes Turkey. (2020). Emeklilik ve Yatırm Fon Raporu 2020. Forbes Turkey.

Gökçen, U., \& Yalçın, A. (2015). The Case Against Active Pension Funds: Evidence from the Turkish Private Pension System. Emerging Markets Review, 23, 46-67.

Hinz, R., Rudolph, H. P., Antolín, P., \& Yermo, J. (2010). Evaluating the Financial Performance of Pension Funds. Washington DC, USA: The International Bank for Reconstruction and Development / The World 
Bank.

http:/ / documents.worldbank.org/curated/en/664431468337199780/pdf/527090PUB0pens101Officia 10Use0only1.pdf

HMB. (2020). Hazine ve Maliye Bakanlığı. www.hmb.gov.tr

Kuzubaş, T. U., Saltoğlu, B., Sert, A., \& Yüksel, A. (2019). Performance Evaluation of The Turkish Pension Fund System. Journal of Capital Markets Studies, 3(1), 18-33.

OECD. (2019). Pension Markets in Focus 2019.

OECD. (2020). Organisation for Economic Co-operation and Development. www.oecd.org

Şahin, S., Özdemir, Z. A., \& Önal, Y. B. (2018). Türkiye'de Bireysel Emeklilik Sisteminin Sermaye Piyasasının Gelişimi Üzerindeki Etkisi. Dokuz Eylül Üniversitesi İktisadi ve İdari Bilimler Fakültesi Dergisi, $33(2), 517-541$

TEFAS. (2020). Türkiye Elektronik Fon Alım Satım Paltformu. www.tefas.gov.tr.

Toğan-Eğrican, A. , \& Kayhan, F. (2020). Voluntary Private Pension Funds and Capital Market Development in Turkey. Working Paper. https://ssrn.com/abstract=3518442

Tonks, I. (2006). Pension Fund Management and Investment Performance. G. L. Clark, A. H. Munnell, \& J. M. Orszag içinde, The Oxford Handbook of Pensions and Retirement Income. 